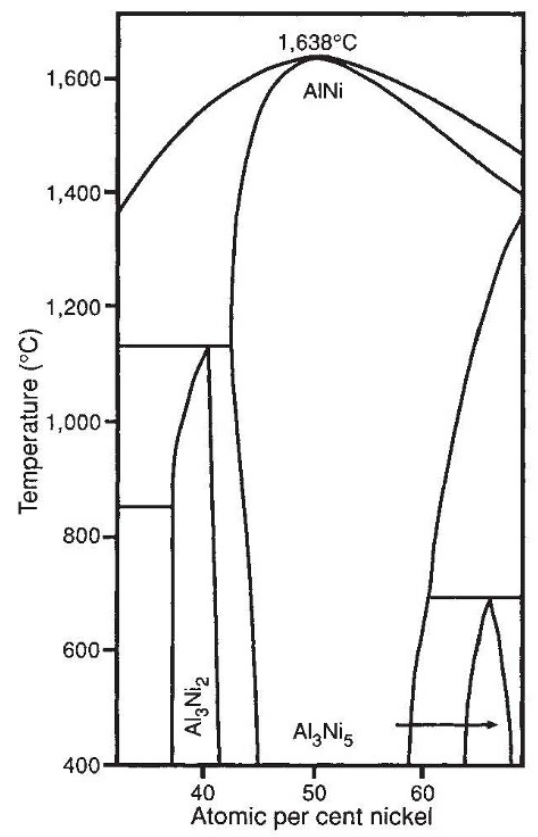

Partial phase diagram for aluminium-nickel alloys $^{8}$ (see text).

Al-rich side, where constitutional vacancies exist, than on the Ni-rich side, where there are none. Such a degree of asymmetry is rather unusual in equilibrium diagrams, and it may not be too fanciful to suggest that there could be a linkage between this feature and the presence of large numbers of vacancies.

Of course, the formation energy of constitutional vacancies is much smaller than that of normal thermal vacancies, and so the increase of the free energy of a crystal containing the former is much less (for a given concentration) than it is for the latter ${ }^{6}$. (The free energy is reduced by the presence of the vacancies, relative to a crystal with excess $\mathrm{Al}$ atoms in $\mathrm{Ni}$ sites, but is increased relative to the perfect crystal.) It might be worth examining more carefully the possible influence of very large concentrations of vacancies in certain compounds on their melting behaviour, particularly as Fecht's calculations show that the critical (Kauzmann) temperature for an intermetallic compound falls at a higher fraction of the normal $T_{\mathrm{m}}$ than it does for a pure metal.

Robert W. Cahn is in the Department of Materials Science and Metallurgy, University of Cambridge, Pembroke Street, Cambridge CB2 3QZ, UK.

1. Fecht, H. J. Nature 356, 133-135 (1992)

2. Fecht, H. J. \& Johnson, W. L. Nature 334, 50-51 (1988)

3. Simon, F. Ann. Physik 68, 278 (1931).

4. Cahn, R. W. Nature 334, 17-18 (1988)

5. Gorecki, T. Scripta metall. 11, 1051-1057 (1977)

6. Cahn, R. W. in Encyclopedia of Materials Science and Engineering (ed. Bever, M. B.) 812 (Pergamon, Oxford, 1986)

7. Bradley, A. J. \& Taylor, A. Proc. R. Soc. A159, 56-72 (1937).

8. Kogachi, M., Minamigawa, S. \& Nakahigashi, K. Acta metall. mater. (in the press).

\section{The making of a mummy}

Paul G. Bahn

THE lid has, it seems, finally been put on a controversy about whether the ancient Egyptians used bitumen when mummifying the dead. In their latest paper on the topic $^{1}$, J. Connan and D. Dessort show unequivocally that bitumen was indeed generally used in mummification, and far earlier than hitherto suspected, and they also pinpoint the most likely sources of the material.

The very word 'mummy' is derived from the Persian 'mumia' meaning bitumen or pitch, and the 'Mummy Mountain' in Persia was famous for the black, bituminous substance that oozed from it and was said to have medicinal properties $^{2}$. From the blackened appearance of many preserved bodies from ancient Egypt (see illustration), it was at first assumed that the corpses had been soaked in bitumen. In more recent times, however, Egyptologists have generally taken it to be the case that the corpses' appearance resulted from their having been coated with resins that eventually turned black $^{3}$

In the late $1980 \mathrm{~s}$, Connan and Dessort, both of whom are geochemists, analysed parts of an Egyptian mummy in the Musée Guimet, Lyon, and discovered traces of bitumen, the characteristics of which pointed to the Dead Sea as the source ${ }^{4}$. Together with similar results ${ }^{5}$, this indicated the use of bitumen in mum- The black is bitumen - an Egyptian mummy of the mies from Ptolemaic and Ptolemaic period (c. first century BC).

Roman times (about $400 \mathrm{BC}$ to $\mathrm{AD} 300$ ).

Connan and Dessort have now ${ }^{1}$ found bitumen in a further dozen mummies dating from the reign of Ramesses II (about $1200 \mathrm{BC}$ ) to the Roman period, thus pushing the practice far back in time. Using petroleum geochemistry techniques, they have identified geochemical 'fossils' (steranes and terpanes) in hydrocarbon fractions of the balms which demonstrate that bitumen was generally an important ingredient in the embalming process. Moreover, on the basis of 15 discriminant molecular parameters, the authors have pointed to two principal sources. The first is again the Dead Sea, where asphalts occur in floating blocks. The other is the region of Hit-Abu Jir in Iraq, from where bitumen used to be exported to Babylon for use as mortar in brick walls ${ }^{6}$.

The value attached to bitumen, reflected in the great distances from which it was imported, may lie simply in its servative properties. But it is also possible that its use on corpses was linked to a belief in rebirth, which was symbolized by the colour black in ancient Egypt. The task that now remains for Connan

IMAGE
UNAVAILABLE
FOR COPYRIGHT
REASONS

and Dessort is to see whether bitumen was also used on the very earliest mummies, those dating from $2600 \mathrm{BC}$ to $1300 \mathrm{BC}$.

Paul G. Bahn, 428 Anlaby Road, Hull HU3 $6 Q P, U K$, is a freelance writer on archaeology.

1. Connan, J. \& Dessort, D. C.r. hebd. Séanc. Acad. Sci. Paris 312, 1445-1452 (1991).

2. David, R. \& Tapp, E. (eds) Evidence Embalmed: Modern Medicine and the Mummies of Ancient Egypt 3 (Manchester University Press, 1984).

3. Lucas, A. \& Harris, J. R. Ancient Egyptian Materials and Industries, 4th edn, 303-308 (Histories and Mysteries of Man Ltd, London, 1962).

4. Connan, J. \& Dessort, D. C.r. hebd. Séanc. Acad. Sci., Paris 309, 1665-1672 (1989).

5. Rullkötter, J. \& Nissenbaum, A. Naturwissenschaften $\mathbf{7 5}$ 618 (1988)

6. Connan, J. \& Deschesne, O. La Recherche 22, 152-159 (1991). supposed medicinal, antiseptic and pre- 